\title{
УДК 636.5.033:636.085.8:636.085.57
}

ДЕМЧИШИН О.В.*, e-mail: sdv25061991@ gmail.com, КУХТИН М.Д., д-р вет. наук, проф., e-mail: kuchtyn@ukr.net, ПЕРКІЙ Ю.Б., канд. вет. наук, ст. наук. сп., е-mail: yperkiy@ukr.net Тернопільська дослідна станиія Інституту ветеринарної медицини НАAН ГОРЮК Ю.В., канд. вет. наук, e-mail: goruky@ukr.net Подільський державний аграрно-технічний університет

\section{ВПЛИВ ПІДКИСЛЮВАЧА «АКВАСАН» НА МІКРОБІОЦЕНОЗ КИШКІВНИКА КУРЧАТ БРОЙЛЕРІВ}

У статті наведено результати впливу випоювання підкислювачем «Аквасан» на мікробіоченоз кишківника курчат бройлерів при вирощуванні. Встановлено, щуо розроблений підкислювач «Аквасан» позитивно впливає на кишковий мікробіоченоз курчат бройлерів $i$ кількість корисної автохтонної мікрофлори (біфідобактерії, лактобактерії) збільшується, в середньому, на один порядок. За випоювання підкислювача кількість умовно-патогенної мікрофлори (Escherichia coli, БГКП) зменшується, а патогенна (Staphylococcus aureus) - не виділяеться у вмістимому шлунково-кишкового тракту.

Ключові слова: курчата бройлери, підкислювач «Аквасан», застосування, мікробіоценоз кишківника.

Вступ. В останні роки спостерігається збільшення використання органічних кислот або підкислювачів при відгодівлі птиці, як замінників антибактеріальних препаратів, через зростання резистентності мікроорганізмів до антибіотиків та наслідки для здоров'я людей [1]. Кислоти та їхні солі сприяють розвитку бажаної мікрофлори у шлунково-кишковому тракті на стартовому етапі розвитку курчат, тим самим очищають травний канал від Salmonella spp., Campylobacter spp. та ін. патогенних бактерій, сприяють профілактиці інфекційних захворювань, підвищенню загальної резистентності організму курчат i збереженості поголів'я. Також вони поліпшують перетравність і засвоєння поживних речовин, підвищують продуктивність птиці та зменшують затрати корму на одиницю виробленої продукції. Довготривале використання органічних кислот у годівлі не адаптує до них мікроорганізми $[2,3]$.

Ефективність дії підкислювачів підвищується, коли ці препарати містять декілька кислот, які, діючи комплексно у волі, залозистому та м'язовому шлунках, знижують рівень $\mathrm{pH}$ і посилюють природний бар'єр цієї ділянки травної системи $[4,5]$. Але більш прогресивними засобами нині є кормові підкислювачі, що складаються із синергічного поєднання комбінацій моно-, дита тригліцеридів жирних кислот, які мають набагато сильніші властивості. Вони діють незалежно від значення $\mathrm{pH}$ повністю на весь шлунково-кишковий тракт, починаючи від вола і закінчуючи тонким, товстим відділами кишківника та клоакою [6].

\footnotetext{
* Аспірант, науковий керівник - Кухтин М. Д.
} 
Нами було створено новий підкислювач «Аквасан» для курчат бройлерів. У склад підкислювала входять мурашина кислота - 30\%, ортофосфорна кислота $15 \%$, молочна кислота - 20\%, пропіонова кислота - 20\%, моно-дигліцериди масляної кислоти $-1,3 \%$, міді сульфат $-0,16 \%$ і вода $-13,54 \%$.

Метою роботи було вивчити вплив застосування підкислювача «Аквасан» на мікробіоценоз кишківника курчат бройлерів при вирощуванні.

Матеріали i методи досліджень. Експериментальні дослідження проводили у фермерському господарстві «Подільська Марка» с. Мушкутинці Дунаєвецького району, Хмельницької області. Дослідження проводили на трьох групах курчат бройлерів породи Ross 308 по 2 тис. голів у кожній. Перша група курчат була контрольна, а друга-третя - дослідними (табл. 1).

Таблиия 1

\section{Схема науково-господарського досліду}

\begin{tabular}{|l|c|c|}
\hline \multicolumn{1}{|c|}{ Групи курчат } & $\begin{array}{c}\text { Кількість курчат у } \\
\text { групах, гол. }\end{array}$ & Особливості годівлі курчат бройлерів \\
\hline I - контрольна & 2000 & ОР \\
\hline II - дослідна & 2000 & OР + «Фідацид Макс Л» 1 мл/1 л води \\
\hline III - дослідна & 2000 & OP + «Аквасан» 1 мл/1 л води \\
\hline
\end{tabular}

Примітка: ОР - основний раціон.

Годівлю курчат у всіх групах проводили збалансованим повнораціонним комбікормом відповідно до норм згідно з віковими періодами вирощування. Протягом періоду вирощування застосовували премікси Предстартер, Стартер, Гроуер та Фінішер. Курчата у контрольній групі отримували лише комбікорм. Курчатам у другій дослідній групі крім повноцінного комбікорму випоювали рідкий підкислювач «FEEDACID MAX L» (Фідацид Макс Л) (мурашина, пропіонова, фосфорна, лимонна, молочна кислоти, амонійні буфери, масло орегано) PANCOSMA S.A. (Швейцарія), а курчатам у третій дослідній групі новий підкислювач «Аквасан». Готували робочий $0,1 \%$ розчин підкислювача «Фідацид Макс Л» на водопровідній воді, корегували $\mathrm{pH}$ розчину у межах 4,3-4,5 од. Випоювання проводили з 27 дня відгодівлі протягом 10 днів (27-31 i 34-38 день) після проведення усіх профілактичних заходів та щеплень курчат. Курчатам у третій дослідній групі випоювання нового підкислювача «Аквасан» проводили за аналогічною схемою з розрахунку 1 л на 1 тону води. Період вирощування тривав 43 доби. Щільність посадки курчат становила 16,4 голів на $1 \mathrm{~m}^{2}$ площі. Утримання курчат підлогове на незмінній підстилці.

Після завершення досліджень (44-45 день) у забійному цеху проводили відбір вмістимого товстого кишківника курчат бройлерів для мікробіологічних досліджень згідно 3 загальноприйнятими методами. Відважували 1 г вмістимого кишківника, готували ряд десятикратних розведень і проводили посів на поживні середовища. Виділення стафілококів проводили на середовищі Baird-Parker Agar, бактерій родини Enterobacteriaceae - на Endo Agar, біфідобактерій - на біфідум середовищі, лактобактерій - на середовищі MRS, стрептококів - на середовищі Гарро, грибів та дріжджів - на середовищі 
Сабуро, а ентерококів - на ентерококагарі. Ідентифікацію виділених мікроорганізмів проводили згідно з 9-им виданням визначника бактерій Берджі [7].

Результати досліджень та їх обговорення. Результати досліджень впливу випоювання підкислювача «Аквасан» на мікрофлору шлунковокишкового тракту курчат бройлерів наведено в табл. 2.

Таблиця 2

\section{Вплив підкислювача «Аквасан» на мікрофлору шлунково-кишкового тракту курчат бройлерів, КУО/г, M \pm m, n = 3}

\begin{tabular}{|l|c|c|c|}
\hline \multirow{2}{*}{\multicolumn{1}{|c|}{ Мікрофлора }} & \multicolumn{3}{|c|}{ Групи курчат } \\
\cline { 2 - 4 } & І (контрольна) & ІІ (дослідна) & ІІІ (дослідна) \\
\hline Bifidobacterium spp. & $2,2 \pm 0,1 \times 10^{7}$ & $5,3 \pm 0,1 \times 10^{8} *$ & $8,7 \pm 0,2 \times 10^{8} *$ \\
\hline Lactobacillus spp. & $7,2 \pm 0,2 \times 10^{7}$ & $4,1 \pm 0,3 \times 10^{8} *$ & $5,6 \pm 0,2 \times 10^{8} *$ \\
\hline Streptococcus spp. & $3,1 \pm 0,1 \times 10^{7}$ & $6,2 \pm 0,2 \times 10^{7} *$ & $6,5 \pm 0,3 \times 10^{7} *$ \\
\hline Enterococcus spp. & $1,3 \pm 0,03 \times 10^{6}$ & $5,8 \pm 0,2 \times 10^{4} *$ & $3,0 \pm 0,2 \times 10^{4} *$ \\
\hline Гриби & $1,6 \pm 0,04 \times 10^{6}$ & $8,1 \pm 0,2 \times 10^{4} *$ & $8,7 \pm 0,1 \times 10^{4} *$ \\
\hline БГКП & $9,3 \pm 0,5 \times 10^{5}$ & $4,3 \pm 0,3 \times 10^{5} *$ & $4,6 \pm 0,4 \times 10^{5} *$ \\
\hline E. coli & $1,5 \pm 0,01 \times 10^{7}$ & $3,9 \pm 0,1 \times 10^{5} *$ & $5,7 \pm 0,2 \times 10^{5} *$ \\
\hline Staphylococcus spp. & $2,7 \pm 0,02 \times 10^{4}$ & $6,8 \pm 0,1 \times 10^{2} *$ & $5,9 \pm 0,02 \times 10^{2} *$ \\
\hline S. aureus & $3,4 \pm 0,2 \times 10^{2}$ & 0 & 0 \\
\hline
\end{tabular}

Примітка: * $-\mathrm{p} \leq 0,001$ - щодо контрольної групи.

3 табл. 2 видно, що розроблений нами підкислювач «Аквасан» позитивно впливав на кишковий мікробіоценоз курчат бройлерів. За випоювання препарату «Аквасан» кількість корисної автохтонної (постійної, резидентної) мікрофлори (біфідобактерії, лактобактерії) збільшувалася на один порядок, зокрема, у 7,8-39,6 рази $(\mathrm{p} \leq 0,001)$, а кількість мікроорганізмів роду Streptococcus - у 2,1 рази $(\mathrm{p} \leq 0,001)$. Отже, зниження $\mathrm{pH}$ кишківника птиці за випоювання підкислювача «Аквасан» створює оптимальні умови для росту i збільшення нормальної мікрофлори шлунково-кишкового тракту курчат.

Аналогічні зміни автохтонної мікрофлори кишківника курчат спостерігали і за випоювання підкислювача аналога «Фідацид Макс Л», але збільшення кількості біфідобактерій та лактобактерій були у 1,4-1,6 рази менші, порівняно із застосуванням підкислювача «Аквасан», а бактерії роду Streptococcus залишалися без змін.

Кількість мікроорганізмів роду Enterococcus та грибів після випоювання підкислювача «Аквасан» зменшувалася у товстому кишківнику на два порядки, у 43,3 та 18,4 рази ( $\mathrm{p} \leq 0,001)$, відповідно. Також зменшення грибів і ентерококів спостерігали у групах курчат за використання підкислювача «Фідацид Макс Л» у 19,8 та 22,4 рази ( $\leq \leq 0,001)$, відповідно.

Випоювання нового підкислювача «Аквасан» призводило до зменшення умовно-патогенних бактерій (БГКП) у мікробіоценозі кишківника курчат III дослідної групи у 2 рази $(\mathrm{p} \leq 0,001)$, а мікроорганізмів E. coli - у 26,3 рази $(\mathrm{p} \leq 0,001)$, що свідчить про бактерицидні властивості робочого 0,1 \% розчину препарату. Патогенні мікроорганізми $S$. aureus не виділялися у вмістимому кишківника після випоювання обох підкислювачів у II та III дослідних групах. 
Попередніми лабораторними дослідженнями було встановлено, що мінімальна бактерицидна концентрація підкислювача «Аквасан» на бактерії S. aureus становить 4\% за експозиції 30 хв, на E. coli - 0,0968\%, а на тест-культури мікроорганізмів Candida spp. - 2\%. Отже, зменшення вмісту кількості БГКП та E. coli відбувається внаслідок бактерицидної дії $0,1 \%$ робочого розчину підкислювача «Аквасан», а зменшення кількості грибів, ентерококів, стафілококів та відсутність мікроорганізмів S. aureus внаслідок створення несприятливих умов (зниження $\mathrm{pH}$ вмістимого кишківника) і антагоністичної дії нормальної мікрофлори шлунково-кишкового тракту (біфідобактерій, лактобактерій), яка інтенсивно збільшується. Тобто, відбувається, так зване, комплексне природне витіснення патогенної та умовно-патогенної мікрофлори 3 кишківника птиці.

3 вищенаведених результатів досліджень видно, що підкислювач «Аквасан» проявляс аналогічну дію на мікрофлору кишківника курчат як i препарат аналог «Фідацид Макс Л» та навіть дещо перевищує його. Новостворений підкислювач «Аквасан» сприяє зростанню кількості автохтонної мікрофлори шлунково-кишкового тракту курчат бройлерів, зменшенню умовно-патогенної мікрофлори і природному звільненню від патогенних мікроорганізмів.

\section{Висновки та перспективи подальших досліджень:}

1. За випоювання підкислювача «Аквасан» кількість автохтонної мікрофлори (біфідобактерії, лактобактерії) товстого кишківника курчат бройлерів збільшується у 7,8-39,6 рази ( $\leq \leq 0,001)$, а кількість мікроорганізмів роду Streptococcus - у 2,1 рази $(\mathrm{p} \leq 0,001)$.

2. Встановлено, що застосування підкислювача «Аквасан» курчатам сприяє зменшенню умовно-патогенних бактерій у мікробіоценозі кишківника у $2-26,3$ рази $\quad(\mathrm{p} \leq 0,001) \quad$ та природному звільненню від патогенних мікроорганізмів $S$. aureus.

Буде вивчено вплив підкислювача «Аквасан» на якість м’яса курчат бройлерів при відгодівлі.

\section{СПИСОК ЛІТЕРАТУРИ}

1. Khan S.H. Recent advances in the role of organic acids in poultry nutrition / S.H. Khan, J. Iqbal // Journal of Applied Animal Research. - 2016. - Vol. 44, №1. - P. 359-369.

2. Коцюмбас I.Я. Проблеми використання антимікробних препаратів для стимулювання росту продуктивних тварин та альтернативи їх застосуванню / І.Я. Коцюмбас, B.M. Гунчак, Т.I. Стецько // Науково-технічний бюлетень Інституту біології тварин i Державного науково-дослідного контрольного інституту ветпрепаратів та кормових добавок. - 2013. - Вип.14. - №3-4. - С. 381-389.

3. Найденский М. Применение органических кислот для развития животных / М. Найденский, Р. Кармолиев, В. Лукачева // Комбикорма. - 2002. - № 7. - С. 53-55.

4. Особенность подхода компании NOVUS к органическим кислотам // Ефективне птахівництво. - 2009. - №12. - С. 22-25.

5. Органические кислоты - эффективная альтернатива стимуляторам роста // Ефективні корми та годівля. - 2010. - №6. - С. 26-28.

6. Сиваченко Є.В. Результати вирощування курчат-бройлерів за додавання органічних кислот до комбікорму / Є.В. Сиваченко, П.М. Каркач // Сучасне птахівництво. - 2014. №10(143). - C. 12-14. 
7. Определитель бактерий Берджи: девятое издание в 2 т. / [под ред. Дж. Хоулта, Н. Крига, П. Скита и др.; перевод с анг. под ред. академ. РАН Г.А. Заварзина]. - М.: Мир, 1994. - T.2. $-430 \mathrm{c}$.

\section{ВЛИЯНИЕ ПОДКИСЛИТЕЛЯ «АКВАСАН» НА МИКРОБИОЦЕНОЗ КИШЕЧНИКА ЦЫПЛЯТ БРОЙЛЕРОВ / Демчишин А.В., Кухтин Н.Д., Перкий Ю.Б., Горюк Ю.В.}

В статье приведень результать влияния выпойки подкислителя "Аквасан» на микробиоченоз кишечника иуыплят бройлеров при выращивании. Установлено, что разработанный подкислитель «Аквасан» положительно влияет на кишечный микробиоченоз иыллят бройлеров и количество полезной автохтонной микрофлоры (бифидобактерии, лактобактерии) увеличивается, в среднем, на один порядок. По выпойке подкислителя количество условно-патогенной микрофлоры (Escherichia coli, БГКП) уменьшается, a патогенная микрофлора (Staphylocoсcиs aureus) не выделяется в содержимом желудочнокишечного тракта.

Ключевые слова: иэыплята бройлеры, подкислитель «Аквасан», применение, микробиоченоз кишечника.

\section{EFFECT OF ACIDIFIER «AKVASAN» ON INTESTINAL MICROBIOCENOSIS OF BROILER CHICKENS / Demchyschyn O.V., Kuhtyn M.D, Perkiy Yu.B., Horiuk Yu.V.}

Introduction. In recent years, there has been an increase in the use of organic acids in poultry fattening as antibiotic substitutes due to the increase of a microorganism's resistance to antimicrobial preparations and the consequences for human health.

The aim of the work was to study the effect of the acidifier «Akvasan» on intestinal microbiocenosis of growing broiler chickens.

Materials and methods. The research was conducted on three groups of the broiler chickens of a line Ross 308 (two thousand birds in each). The chickens of a control group received only feed. The chickens of the second experimental group, in addition to the complete feed, were given the liquid acidifier "FEEDACID MAX L», and the third experimental group's chickens - the new acidifier "Akvasan" in the volume 1 liter per tonne of water.

Results of research and discussion. It was established that the amount of useful autochthonous microflora increased by an order of magnitude via drinking the drug «Akvasan». The number of microorganisms of the genus Enterococcus, Staphylococcus and fungi after giving of the acidifier "Akvasan» decreased by two orders of magnitude in the large intestine, in 43.3, 45.8 and 18.4 times $(p \leq 0.001)$, respectively.

Including the new acidifier "Akvasan» in the water lead to decreasing of the opportunistic bacteria in the intestinal microbiocenosis of the chickens in third experimental group in 2 times ( $p \leq$ $0.001)$, and E. coli microorganisms - in 26.3 times $(p \leq 0.001)$, which suggests that the $0.1 \%$ solution of the "Akvasan» had bactericidal properties. S. aureus pathogenic microorganisms were not isolated in the intestine after use of both acidic substances.

It was found that the acidifier "Akvasan» showed a similar effect on the chicken's intestinal microflora as its analogue "FEEDACID MAX L" and even slightly above it.

\section{Conclusions and prospects for further research:}

1. The amount of autochthonous microflora (bifidobacteria, lactobacillus) in the large intestine of broiler chickens increased in 7.8-39.6 times ( $\leq \leq 0.001)$, while the number of microorganisms of the genus Streptococcus decreased in 2.1 times ( $p \leq 0.001)$.

2. It was established that the use of the acidifier "Akvasan" in chickens reduce the number of opportunistic bacteria in the intestinal microbiocenosis in $2-26.3$ times $(p \leq 0,001)$ and the natural release from pathogenic bacteria S. aureus. 
The influence of the acidifier «Akvasan» on the meat quality of broiler chickens in fattening will be studied.

Keywords: broiler chickens, the acidifier "Akvasan", application, intestinal microbiocenosis.

\section{REFERENCES}

1. Khan, S.H. \& Iqbal, J. (2016). Recent advances in the role of organic acids in poultry nutrition. Journal of Applied Animal Research, Vol. 44, 1, 359-369.

2. Kocjumbas, I.Ja., Gunchak, V.M. \& Stec'ko, T.I. (2013). Problemy vykorystannja antymikrobnyh preparativ dlja stymuljuvannja rostu produktyvnyh tvaryn ta al'ternatyvy i'h zastosuvannju [Problems of using antimicrobial drugs to stimulate the growth of productive animals and alternative to their use]. Naukovo-tehnichnyj bjuleten' Instytutu biologii' tvaryn i Derzhavnogo naukovo-doslidnogo kontrol'nogo instytutu vetpreparativ ta kormovyh dobavok - Scientific and technical bulletin of the Institute of Animal Biology and the State Scientific and Research Control Institute of Veterinary Preparations and Feed Additives, Vol. 14, 3-4, 381-389 [in Ukrainian].

3. Najdenskyj, M., Karmolyev, R. \& Lukacheva ,V. (2002). Primenenie organicheskih kislot dlja razvitija zhivotnyh [The use of organic acids for the development of animals]. Kombikorma - Mixed fodder, Vol. 7, 53-55 [in Russian].

4. Osobennost' podhoda kompanii NOVUS k organicheskim kislotam [Feature of NOVUS approach to organic acids]. (2009). Efektyvne ptahivnyctvo - Effective poultry farming, Vol. 12, 22-25 [in Russian].

5. Organicheskie kisloty - jeffektivnaja al'ternativa stimuljatoram rosta [Organic acids are an effective alternative to growth stimulants]. (2010). Efektyvni kormy ta godivlja - Effective feed and nutrition, Vol. 6, 26-28 [in Ukrainian].

6. Syvachenko, Je.V. \& Karkach, P.M. (2014). Rezul'taty vyroshhuvannja kurchat-brojleriv za dodavannja organichnyh kyslot do kombikormu [Results of growing chicken broilers for the addition of organic acids to feed]. Suchasne ptahivnyctvo - Modern poultry farming, Vol. 10, 143, 12-14 [in Ukrainian].

7. Houlta, Dzh., Kryga, N., Skyta, P. et al. (1994). Opredelitel' bakterij Berdzhi [The Berjee bacteria determinant]. (Vols. 1-2). (Ed. RAN G.A. Zavarzina, Trans). Moscow: Mir [in Russian]. 